Check for updates

Cite this: RSC Adv., 2017, 7, 41640

Received 21st July 2017

Accepted 16th August 2017

DOI: $10.1039 / \mathrm{c} 7 \mathrm{ra0} 0041 \mathrm{~g}$

rsc.li/rsc-advances

\section{Chiisanoside, a triterpenoid saponin, exhibits anti-tumor activity by promoting apoptosis and inhibiting angiogenesis}

\begin{abstract}
Xingbo Bian, (D) a Yan Zhao, (D) *a Xue Guo, (D) a Lianxue Zhang, (D) a Pingya Li, ${ }^{\text {b }}$ Tianhua Fu, (D) ${ }^{a}$ Weidong Wang, (D) ${ }^{a}$ Yongxia Yin, ${ }^{a}$ Guilin Chen (D) a and Jinping Liu ${ }^{\star b}$

The leaves of the Acanthopanax species have traditionally been used as a tonic and sedative, as well as in the treatment of rheumatism and diabetes, and one of their main active ingredients is a lupane triterpenoid chiisanoside which exhibits a series of significant pharmacological effects. However, the anti-tumor activity of chiisanoside on $\mathrm{H}_{22}$ hepatocellular carcinoma and the pharmacokinetics study have not been mentioned. The aim of this study was to explore the anti-tumor efficacy, the potential mechanisms in a $\mathrm{H}_{22}$ tumor-bearing mice model, and the pharmacokinetics properties and tissue distribution characteristics in a rat model. The results revealed that chiisanoside exhibited significant inhibition of tumor cell growth with no side effects on immune organs. The plasma cytokine levels of IL-2, TNF- $\alpha$, and IFN- $\gamma$ were enhanced, whereas the plasma VEGF level was decreased after chiisanoside treatment. Moreover, the results of H\&E, TUNEL assay, immunohistochemistry showed that chiisanoside exhibited antitumor activity in vivo by promoting apoptosis and inhibiting angiogenesis. Additionally, further investigations on the pharmacokinetics revealed that chiisanoside had a trait of fast absorption and rapid elimination in rat. Furthermore, the results of tissue distribution showed that chiisanoside was mainly distributed in the liver, small intestine and other organs in rat, which indicated that chiisanoside exhibited good liver and small intestine-targeting efficiency.
\end{abstract}

\section{Introduction}

The incidence of hepatocellular carcinoma (HCC) is only second to that of gastric and esophageal cancer among all tumors and one of the most common malignant tumors in China. ${ }^{1}$ Also, the incidence of HCC is highest in Asia and sub-Saharan Africa, as well as in western countries. ${ }^{2}$ HCC has become a serious disease which threatens global public health and it is the third leading cause of cancer-related deaths. ${ }^{3}$ In recent years, many domestic and international scholars have regarded the anti-tumor effect of triterpenoids as a key focus. ${ }^{4-6}$ Correspondingly, a large number of triterpenoids for use against various cancers, such as breast cancer, lung carcinoma, hepatic carcinoma, colon cancer and so on have been discovered..$^{7-12}$

Most plants of the Acanthopanax species are safe and nontoxic, especially the leaves of A. sessiliflorus and A. senticosus, which can be eaten as traditional vegetables and tea in China. The leaves of Acanthopanax species, such as A. sessiliflorus, A. senticosus, A. divaricatus, A. subinermis, A. koreanus and so on, have traditionally been used as a tonic and sedative, as well as in

${ }^{a}$ College of Chinese Medicinal Materials, Jilin Agriculture University, Changchun, 130118, Jilin, China. E-mail: zhaoyan@jlau.edu.cn; Fax: +86 431 84533358; Tel: +8643184533358

${ }^{b}$ School of Pharmaceutical Sciences, Jilin University, Changchun, 130021, Jilin, China. E-mail: liujp@jlu.edu.cn; Fax:+86431 85619803; Tel: +8643185619803 the treatment of rheumatism and diabetes, and one of their main active ingredients is a lupane triterpenoid chiisanoside, ${ }^{13-15}$ which exhibits a series of significant pharmacological effects, such as anti-osteoporosis, ${ }^{16}$ anti-inflammation, ${ }^{17-20}$ antibacterial, ${ }^{21}$ anti-platelet aggregating, ${ }^{22}$ treatment of glycationassociated diseases, ${ }^{23}$ anti-rotaviral, ${ }^{24}$ and the inhibition of lipase. ${ }^{25,26}$ However, the reports related to the effects of chiisanoside on hepatic carcinoma, and the pharmacokinetics properties and tissue distribution characteristics have not been found.

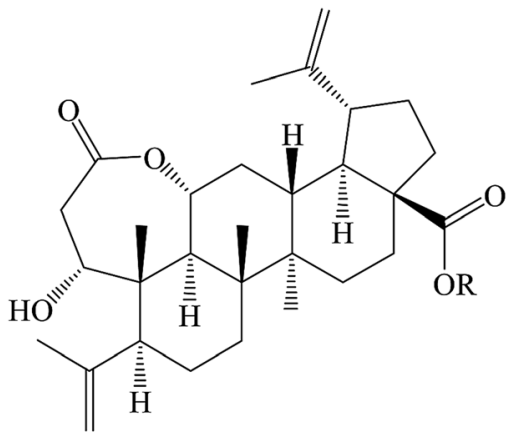

$\mathrm{R}=-\beta-\mathrm{D}-\mathrm{Glc}-(1 \rightarrow 6)-\beta-\mathrm{D}-\mathrm{Glc}-(1 \rightarrow 4)-\alpha-\mathrm{L}-\mathrm{Rha}$

chiisanoside 
In this study, the anti-tumor efficacy of chiisanoside, and the potential mechanisms were studied in a $\mathrm{H}_{22}$ tumor-bearing mice model. To make it clear how chiisanoside exert the effect, the pharmacokinetics and tissue distribution after intravenous infusion administration were evaluated. What this study has carried out was to provide a certain basis for clinical application or enlarge the use of the leaves of Acanthopanax species.

\section{Material and methods}

\subsection{Preparation of chiisanoside}

The fresh leaves of $A$. sessiliflorus were collected in July, 2015 in Linjiang of Jilin Province, China, and were identified by Prof. Lianxue Zhang. The voucher specimen was deposited at the laboratory.

The air-dried leaves (5 kg, 60-mesh) were extracted three times with $70 \%$ ethanol in an ultrasonic generator $(3000 \mathrm{~W}, 40$ $\mathrm{kHz}, \mathrm{KQ}-3000 \mathrm{~B}, \mathrm{Kunshan}, \mathrm{China})$, each time $40 \mathrm{~min}$. The extract was filtered, combined and concentrated under reduced pressure to no alcohol odor, and then passed through a D101 macroporous resin column, washed with water to the distillate without color, then eluted with $50 \%$ ethanol, collected the distillate and concentrated to dryness to give total triterpenoid saponins (893 g). Part of total triterpenoid saponins (150 g) was chromatographed on a silica gel column with chloroformmethanol $(5: 1)$ to afford chiisanoside $(28.5 \mathrm{~g})$. The purity of chiisanoside was determined by HPLC (purity $>98 \%$ ), and the structure was identified by ${ }^{1} \mathrm{H}$ NMR and ${ }^{13} \mathrm{C}$ NMR. ${ }^{26}$

\subsection{Cells and animals}

Mouse hepatoma $22\left(\mathrm{H}_{22}\right)$ cell line was obtained from Institute of Biochemistry and Cell Biology, SIBS, CAS. Murine $\mathrm{H}_{22}$ cells were maintained in the ascitic form by sequential passages in male ICR mice.

ICR mice (male, weighing 18-22 g, SPF grade) and Wistar rats (male, weighing 180-220 g, SPF grade) were purchased from Experimental Animal Quality Testing Center (Certificate no. SCXK 2011-0004, Jilin, China). Animals were kept in standard laboratory conditions: room temperature at $23 \pm 2{ }^{\circ} \mathrm{C}$, humidity of $60 \pm 10 \%$. And the mice were allowed free access to diet and water during the experiments. All experiments were carried out in accordance with the Guide for Animal Experimentation of Jilin Agricultural University. The protocol was approved by the Jilin Agricultural University Institutional Animal Care and Use Committee.

\section{3 $\quad \mathrm{H}_{22}$ tumor-bearing mouse model establishment and animal treatment}

The $\mathrm{H}_{22}$ tumor-bearing mouse model was established as previously described. ${ }^{27}$ The $\mathrm{H}_{22}$ tumor-bearing mice were randomly divided into 5 groups $(n=10)$. Drug administration began after $24 \mathrm{~h}$ and was treated once a day for 10 days. According to our previous study about the $\mathrm{LD}_{50}$ of chiisanoside $\left(3.6 \mathrm{~g} \mathrm{~kg}^{-1}\right)$ and the preliminary experiment, the groups for chiisanoside administration were respectively given different dosages (60,
120, $240 \mathrm{mg} \mathrm{kg}^{-1}$ ). Moreover, chiisanoside which was mentioned above was dissolved in $10 \%$ propylene glycol and diluted with saline to different concentration. The positive control group was treated with cyclophosphamide (CTX, $30 \mathrm{mg} \mathrm{kg}{ }^{-1}$ ), while normal group and the model group mice were received $0.9 \%$ normal saline. All groups were treated by intraperitoneal injection. The administration operators were blind to the tested materials, and the testers were also blind to the drug treatment.

All mice were weighed every day, and sacrificed 10 days later. All of the mice of each group were weighed, collected blood samples, sacrificed, and then organs were collected to detect the inhibition rate and organ indices, respectively. The tumor inhibitory rate (TIR) was calculated by the following formula: TIR $(\%)=$ (tumor weight of control group - tumor weight of treated group)/tumor weight of control group $\times 100 \%$. The organ indices were calculated as follows: organ index $\left(\mathrm{mg} \mathrm{g}^{-1}\right)=$ organ weight/body weight (values in formula were the average of each group).

\subsection{Blood biochemical parameters determination}

All blood samples were collected in heparinized tubes, then centrifuged at $3000 \mathrm{rpm}$ for $10 \mathrm{~min}$. The plasma segregated was used for examining biochemical parameters, including alanine aminotransferase (ALT) and aspartate aminotransferase (AST) were determined by kits (Nanjing Jiancheng Bioengineering Institute, Nanjing, China). Cytokines such as tumor necrosis factor- $\alpha$ (TNF- $\alpha$ ), interferon- $\gamma$ (IFN- $\gamma$ ), interleukin (IL-2), and vascular endothelial growth factor (VEGF) were examined according to the instructions of ELISA Kits (Bio-Rad, California, USA).

\subsection{H\&E staining assay}

H\&E staining was performed as previously described. ${ }^{28}$ Briefly, tumor and spleen tissues were fixed with $4 \%$ formaldehyde solution. After deparaffinized with xylene, those tissues were dehydrated with different concentrations of ethanol and cut at 5 $\mu \mathrm{m}$ thick sections. Then the sections were stained with haematoxylin and restained with eosin for minutes, respectively. They were observed by using optical microscope (Olympus, BX51T-PHD-J11, Japan) for histopathological examination.

\subsection{TUNEL staining assay}

TUNEL staining assay was used to further detect the apoptotic cells of tumor tissues. Steps were as follows. ${ }^{29}$ Tumor tissue sections were incubated with protease $\mathrm{K}$ at room temperature for $15 \mathrm{~min}$ and washed with PBS (PH = 7.4-8.0) two times. Let the sections dry, adding TUNEL reaction mixed solution and putting sections to humid chamber at $37{ }^{\circ} \mathrm{C}$ for $1 \mathrm{~h}$. Subsequently, the sections were incubated with conversion agent POD for 30 min after washing with PBS three times, then added DAB substrate solution. Finally, counterstained with haematoxylin to observe. 


\subsection{Immunohistochemistry}

Immunohistochemistry analysis ${ }^{30}$ was performed according to the instruction of SP immunohistochemical kit. Steps were as follows: $5 \mu \mathrm{m}$ thick sections were deparaffinized with xylene and hydrated with respectively descending concentrations of ethanol solution. The sections were incubated in methanol containing $1 \%$ hydrogen peroxide for $10 \mathrm{~min}$ and washed with water, $\mathrm{PBS}(\mathrm{pH}=7.4-8.0)$ for $5 \mathrm{~min}$. Then put sections into citrate buffer solution $(0.01 \mathrm{M}, \mathrm{pH}=6)$ and heated. When the temperature came to $25{ }^{\circ} \mathrm{C}$, the sections were washed three times with PBS. After that, incubated with goat serum sealing solution for $20 \mathrm{~min}$. Sections were incubated in a humidified chamber at $4{ }^{\circ} \mathrm{C}$ overnight with primary antibodies against Bax, Bcl-2, caspase-3 and VEGF, followed by secondary antibody for $20 \mathrm{~min}$, besides streptavidin-antibiotin horseradish peroxidase. At the end of experiment, the sections followed by DAB staining and counterstained with haematoxylin. The immunostaining results were analyzed by light microscopy.

\subsection{Pharmacokinetics and distribution study}

2.8.1 HPLC analysis. Analytical procedure was performed using CXTH-3000 HPLC chromatographic system. The column was Odyssll $\mathrm{C}_{18}(200 \mathrm{~mm} \times 4.6 \mathrm{~mm}, 5 \mu \mathrm{m})$ and temperature was maintained at $40{ }^{\circ} \mathrm{C}$, with detection wavelength of $205 \mathrm{~nm}$. The mobile phase was acetonitrile-water $(35: 65, \mathrm{v} / \mathrm{v})$, at a flow rate of $1.0 \mathrm{~mL} \mathrm{~min}^{-1}$.

2.8.2 Calibration curve. The stock standard solution of chiisanoside was prepared in methanol at a concentration of $1.0 \mathrm{mg} \mathrm{mL} \mathrm{m}^{-1}$. A certain amount of working solutions were added into blank rat plasma or tissue homogenates to obtain final concentrations of $0.1,0.5,1,2.5,5,10,25,50,100,200$ and $500 \mu \mathrm{g} \mathrm{mL}{ }^{-1}$ as calibration standards. Ginsenoside Rd was considered as internal standard solution, which was prepared at a concentration of $100 \mu \mathrm{g} \mathrm{mL} \mathrm{m}^{-1}$ in methanol. All the solutions were stored at $4{ }^{\circ} \mathrm{C}$. And then the working solutions were detected by HPLC. The calibration curves for chiisanoside in plasma and tissues were respectively generated by plotting the peak area ratio $(y)$ of chiisanoside to ginsenoside $\mathrm{Rd}$ versus concentrations of chiisanoside $(x)$.

2.8.3 Sample preparation. The frozen biosamples were thawed at room temperature. A $100 \mu \mathrm{L}$ biosample, $50 \mu \mathrm{L}$ Rd (100 $\mu \mathrm{g} \mathrm{mL}^{-1}$ ginsenoside $\mathrm{Rd}$ dissolved in methanol) and $0.35 \mathrm{~mL}$ methanol were transferred into tubes. The mixture solution was vortexed for $1 \mathrm{~min}$, and the protein was precipitated by centrifugation at $12000 \mathrm{rpm}$ for $10 \mathrm{~min}$ at $4{ }^{\circ} \mathrm{C}$. Moreover, the supernatant was pipetted into tube and dried at $40{ }^{\circ} \mathrm{C}$ under $\mathrm{N}_{2}$. At last, the residue was dissolved with $100 \mu \mathrm{L}$ methanol, shaken by a vortex mixer for $3 \mathrm{~min}$. After centrifuging at $12000 \mathrm{rpm}$ for $10 \mathrm{~min}, 20 \mu \mathrm{L}$ of supernatant fluid was detected by HPLC. ${ }^{31,32}$

2.8.4 Pharmacokinetics study in rats. Rats for pharmacokinetics study were male Wistar, weighing 180-220 g. 18 rats were randomly divided into three different dose groups which were respectively given 42, 84 and $168 \mathrm{mg} \mathrm{kg}^{-1}$ of chiisanoside by tail intravenous infusion, 6 rats in each. Each group was given specific chiisanoside solution of $3 \mathrm{~mL}$ within $15 \mathrm{~min}$. Blood samples of $0.3 \mathrm{~mL}$ were collected from orbit into heparinized Eppendorf tubes at 0.033, 0.083, 0.167, 0.25, 0.33, 0.5, $0.75,1,1.5,2,2.5,3,4,6$ and 8 h. Plasma were separated after centrifuging at $12000 \mathrm{rpm}$ for $10 \mathrm{~min}$.

2.8.5 In vivo tissue distribution. Rats were given $84 \mathrm{mg} \mathrm{kg}^{-1}$ of chiisanoside and were sacrificed at 2, 10 and 40 min after administration, then collected tissues of liver, heart, spleen, lung, kidney, stomach, brain and small intestine. All tissue samples were rinsed with saline and dried by filter paper. Tissues were weighed and homogenized by saline solution at the concentration of $0.2 \mathrm{~g} \mathrm{~mL}^{-1}$.

\subsection{Statistical analysis}

Pharmacokinetics parameters were estimated by a noncompartmental method with the aid of DAS (Drug and Statistics) 3.2.2 software (BioGuider Co., Shanghai, China). Statistical analysis were performed by ANOVA using SPSS 16.0. All data were expressed as the mean \pm SD. Values of $P<0.05$ was considered to be significant and $P<0.01$ highly statistically significant.

\section{Results}

\subsection{Effect of chiisanoside on tumor growth in $\mathrm{H}_{22}$ tumor- bearing mice}

The anti-tumor effect of chiisanoside in vivo was assessed using a $\mathrm{H}_{22}$ tumor-bearing mice model, and the results were summarized in Table 1 . At the end of the experiment, the average tumor weight in negative control group was $0.94 \pm$ $0.33 \mathrm{~g}$. The average tumor weights in chiisanoside groups were gradually decreased with a dose-dependent manner. And it was

Table 1 Effect of chiisanoside on tumor growth and organ indices in $\mathrm{H}_{22}$ tumor-bearing mice ${ }^{a}$

\begin{tabular}{|c|c|c|c|c|c|c|}
\hline Treatment & Dosage/(mg kg $\left.{ }^{-1}\right)$ & Liver index $/\left(\mathrm{mg} \mathrm{g}^{-1}\right)$ & Spleen index $/\left(\mathrm{mg} \mathrm{g}^{-1}\right)$ & Thymus index/(mg g $\left.{ }^{-1}\right)$ & Tumor weight/g & TIR/\% \\
\hline Untreated\# & - & $45.13 \pm 1.53$ & $5.65 \pm 0.32$ & $1.45 \pm 0.43$ & - & - \\
\hline Untreated $\dagger$ & - & $50.33 \pm 1.83$ & $6.18 \pm 0.43$ & $1.84 \pm 0.41$ & $0.94 \pm 0.33$ & - \\
\hline \multirow[t]{3}{*}{ Chiisanoside $\dagger$} & 60 & $48.08 \pm 2.06^{*} \Delta \triangle$ & $5.88 \pm 0.51^{\triangle} \Delta$ & $1.57 \pm 0.37^{\triangle}$ & $0.60 \pm 0.21 * *$ & 36.09 \\
\hline & 120 & $46.86 \pm 3.23^{* * \Delta}$ & $5.18 \pm 0.74^{* * \Delta}$ & $1.73 \pm 0.49$ & $0.37 \pm 0.15^{* *}$ & 60.83 \\
\hline & 240 & $45.53 \pm 1.12^{* * \triangle}$ & $5.74 \pm 0.54^{* \Delta \Delta}$ & $1.47 \pm 0.41^{*}$ & $0.32 \pm 0.13^{* *}$ & 66.45 \\
\hline
\end{tabular}

${ }^{a}$ Values were expressed as mean $\pm \mathrm{SD}, n=10 .{ }^{*} P<0.05,{ }^{* *} P<0.01$ vs. untreated $\dagger,{ }^{\triangle} P<0.05,{ }^{\triangle}{ }^{*} P<0.01$ vs. CTX $\dagger\left(\#=\right.$ normal ICR mice, $\dagger=\mathrm{H}_{22}$ tumor-bearing ICR mice). 


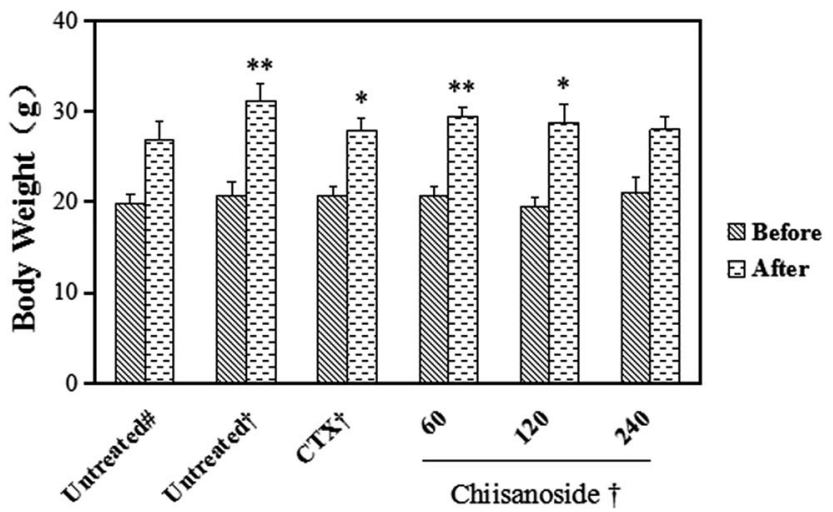

Fig. 1 Effect of chiisanoside on body weights from $\mathrm{H}_{22}$ tumor-bearing mice. Values were expressed as mean $\pm \mathrm{SD}, n=10$. ${ }^{*} P<0.05, * * P<0.05$ vs. untreated\# (\# = normal ICR mice, $\uparrow=\mathrm{H}_{22}$ tumor-bearing ICR mice).

simple to find that tumor inhibitory rate of chiisanoside treated 120 and $240 \mathrm{mg} \mathrm{kg}^{-1}$ were significantly higher than $60 \mathrm{mg} \mathrm{kg}^{-1}$, and the discrepancy of average tumor weights between CTX treated and chiisanoside treated $120,240 \mathrm{mg} \mathrm{kg}^{-1}$ was not so prominent. It was a remarkable fact that chiisanoside treated $240 \mathrm{mg} \mathrm{kg}{ }^{-1}$ showed the highest tumor inhibition rate $(66.45 \%)$. As for body weights, the average body weight of tumor-bearing mice was dramatically increased compared with that of normal $(P<0.05)$, except that of chiisanoside treated $240 \mathrm{mg} \mathrm{kg}^{-1}$ which was closed to that of normal (Fig. 1A).

\subsection{Effect of chiisanoside on organ indices in $\mathrm{H}_{22}$ tumor- bearing mice}

The liver index of all groups (Table 1) and plasma parameters of hepatic function were determined (Fig. 2A), including plasma enzyme activity of ALT and AST. The results showed that liver indices of CTX and chiisanoside administrated mice were decreased, so were the plasma enzyme activity of ALT and AST. As is known, liver damage may be more serious with the two plasma enzyme activity increased. Those above indicated chiisanoside may improve hepatic function.

Thymus and spleen are two important indices on immune system. As for value of negative control group compared with
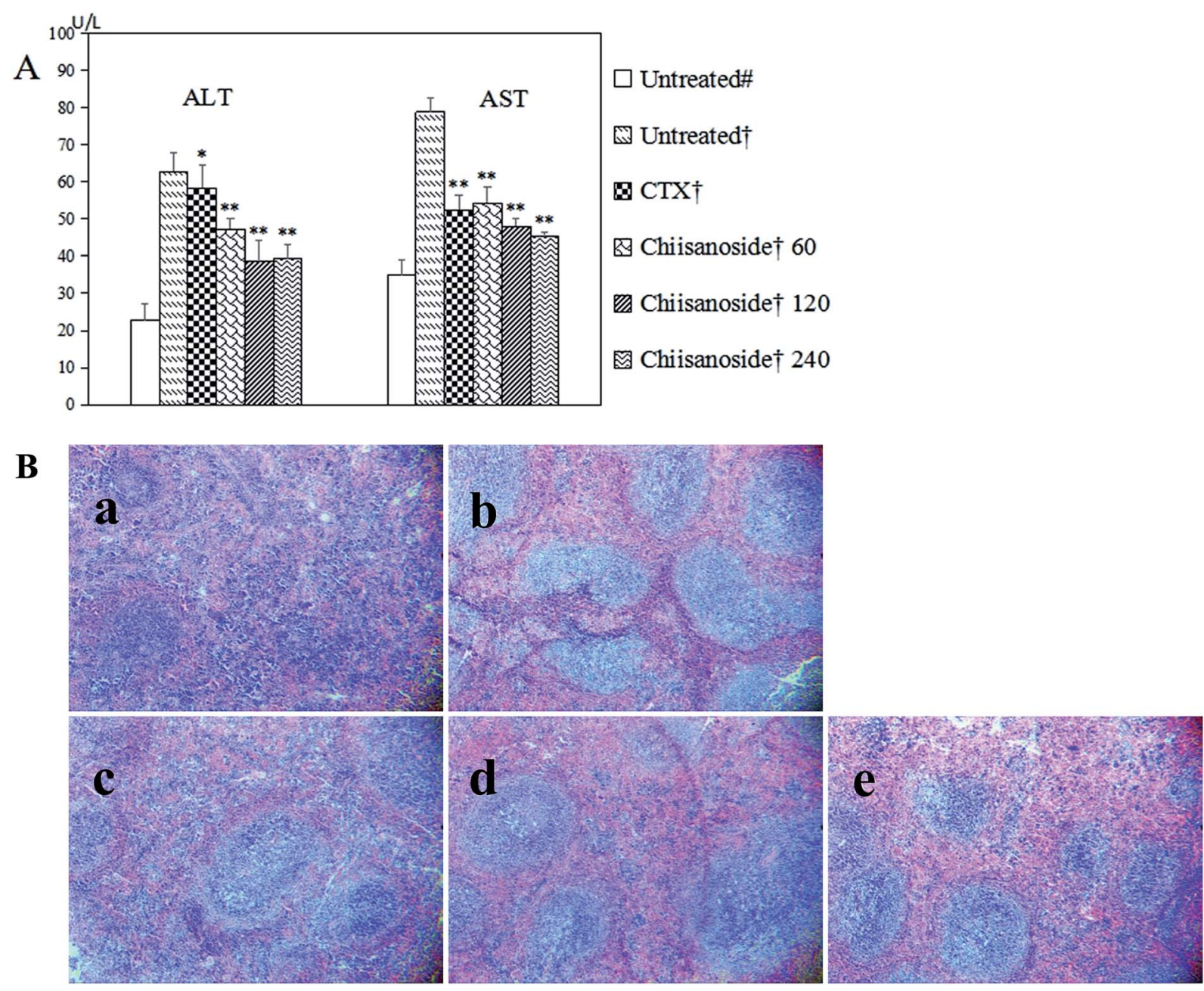

Fig. 2 Effects of chiisanoside on liver function and spleen pathology from $\mathrm{H}_{22}$ tumor-bearing mice. (A) Effects of chiisanoside on ALT and AST.

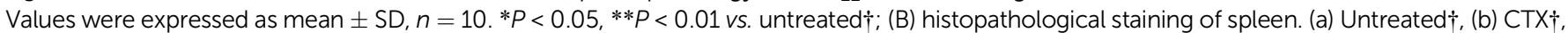
(c) chiisanoside $\uparrow 60 \mathrm{mg} \mathrm{kg}^{-1}$, (d) chiisanoside $\dagger 120 \mathrm{mg} \mathrm{kg}^{-1}$, (e) chiisanoside $\uparrow 240 \mathrm{mg} \mathrm{kg}^{-1}$ (\# = normal ICR mice, $\uparrow=\mathrm{H}_{22}$ tumor-bearing ICR mice). 
others, the results showed higher value. Instead, values of CTX treated mice were the lowest on spleen and thymus indices $(P<$ 0.01 ), which was conformed side effect on immunity. Values of mice in chiisanoside groups were lower than that of negative control group, which indicated chiisanoside treated could improve the immune function. To evaluate further, the histopathological staining of spleen was operated, the result was shown in Fig. 2B, the border between the red pulp and white pulp in the chiisanoside and CTX treated mice is clearer compared with that in model control group.

\subsection{Effect of chiisanoside on plasma cytokines in $\mathrm{H}_{22}$ tumor- bearing mice}

The plasma levels of IL-2, TNF- $\alpha$ and IFN- $\gamma$ were determined by ELISA assay. Those three cytokine levels are important to human body. As shown in Fig. 3, plasma levels of IL-2, TNF$\alpha$ and IFN- $\gamma$ in chiisanoside groups were higher than those in model control group in a dose-dependent manner. The levels in CTX treated group were a little higher compared with model control group, except the level of IFN- $\gamma$.

VEGF plays an important role in process of tumor growth, it is a way to evaluate the antiangiogentic effect of chiisanoside in vivo. The results showed that the level of VEGF were significantly decreased by CTX and chiisanoside treatment compared with that of the model group $(P<0.01)$.

\subsection{Morphological changes by treatment of chiisanoside}

According to the tumor tissue sections in $\mathrm{H}_{22}$ tumor-bearing mice, the cell growth and shape was observed by H\&E staining (Fig. 4A and B). The results showed that there was a large number of cell nuclei in model control group, arranged tightly and stained deeply. However, tumor cells in CTX and chiisanoside treated groups exposed significant morphology alterations. In the tumor tissues of CTX and chiisanoside $120 \mathrm{mg} \mathrm{kg}^{-1}$ and $240 \mathrm{mg} \mathrm{kg}^{-1}$ treated groups, a large area of necrosis, and fragmented and shrank nuclear had been found in a dose-dependent manner, which was typical of apoptotic cells.

TUNEL assay can be used to detect DNA strand breaks that are associated with apoptosis. ${ }^{33}$ To further make sure whether chiisanoside treatment could induce cell apoptosis in $\mathrm{H}_{22}$ transplanted tumors, TUNEL assay was performed (Fig. 4C). The inhibition effect on tumor cells was represented by the color stained, and positive staining was in brown. The results showed that chiisanoside treated with $120 \mathrm{mg} \mathrm{kg}^{-1}$ and $240 \mathrm{mg} \mathrm{kg}$ caused increase of positive cells, so did CTX group. In conclusion, chiisanoside can promote the apoptosis.

\subsection{Expression of apoptosis-related proteins by immunohistochemistry}

Bax and caspase- 3 are pro-apoptotic proteins, Bcl-2 and VEGF are anti-apoptotic. ${ }^{34}$ In order to explore the mechanism about anti-tumor efficacy, the expression levels of these four proteins mentioned above were detected by immunohistochemical analysis, in which cells stained in yellow and browned color were the positive cells. The results were displayed in Fig. 5.

For pro-apoptotic proteins, CTX and chiisanoside treated could increase the Bax and caspase- 3 proteins compared with
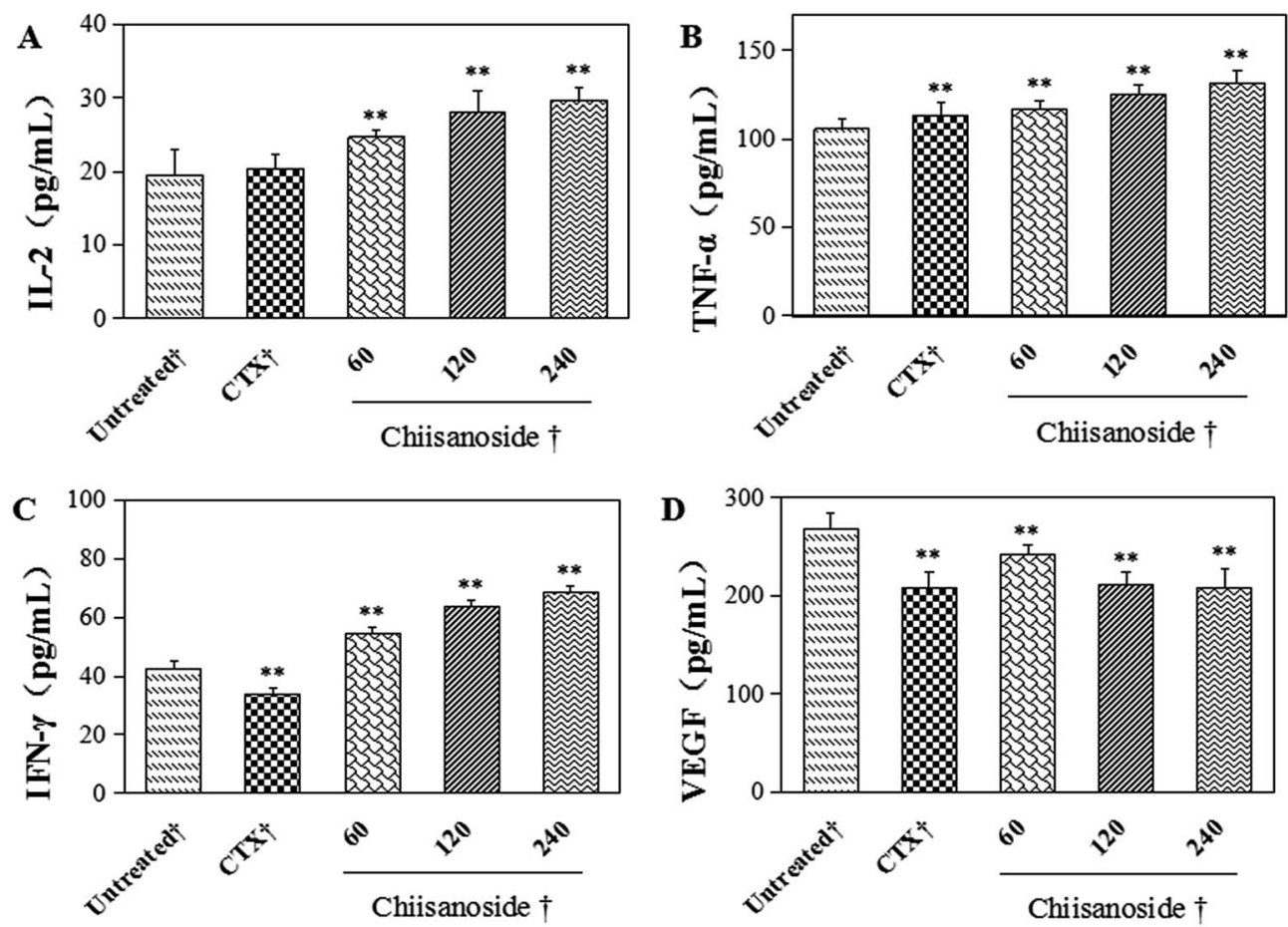

Fig. 3 Effects of chiisanoside on plasma cytokines from $\mathrm{H}_{22}$ tumor-bearing mice. (A) IL-2, (B) TNF- $\alpha$, (C) IFN- $\gamma$, (D) VEGF. All values were expressed as mean $\pm \mathrm{SD}, n=10$. $* P<0.05, * * P<0.01$ vs. untreated $\dagger$ ( $\dagger=\mathrm{H}_{22}$ tumor-bearing ICR mice). 

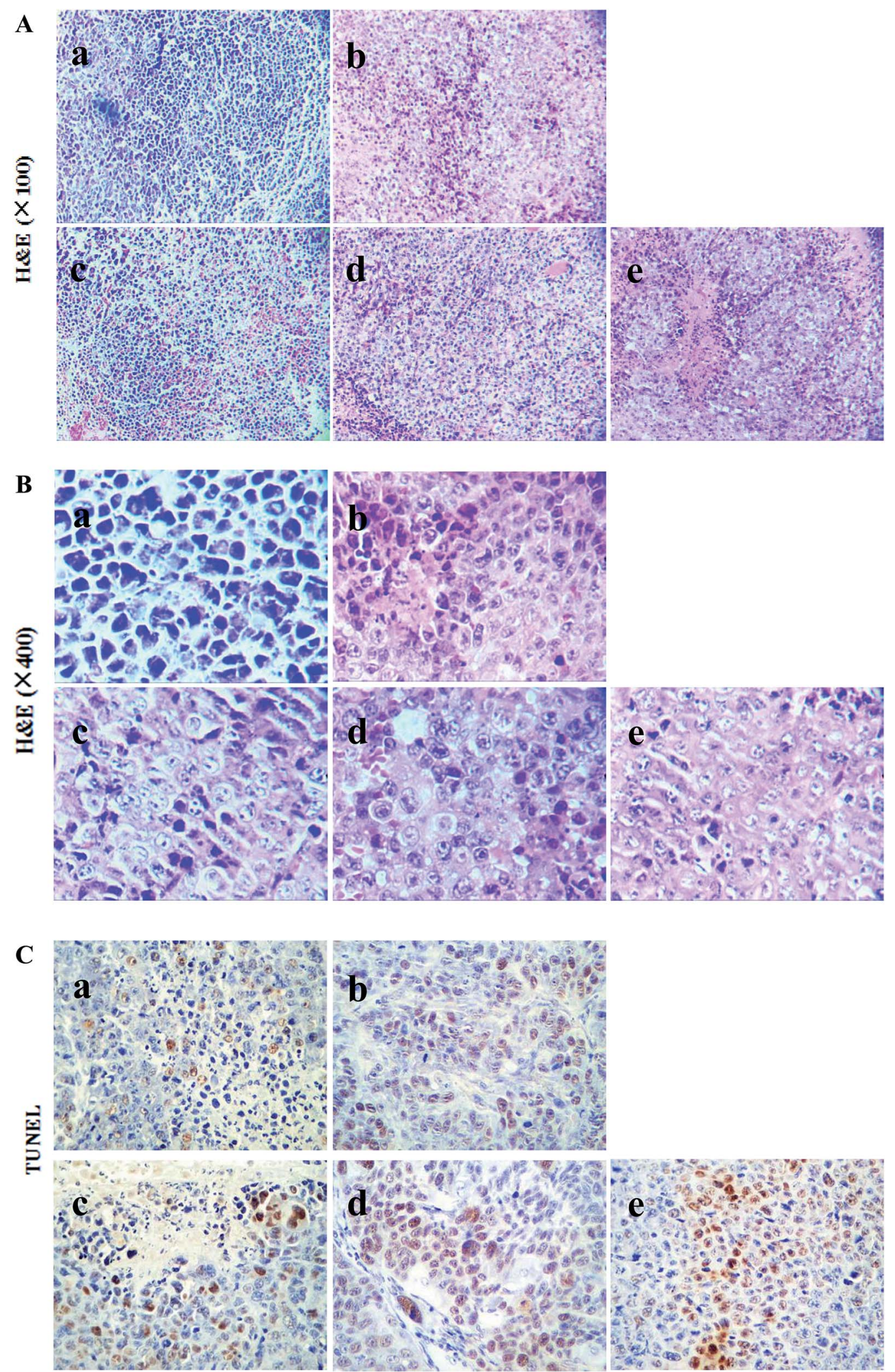

Fig. 4 Morphological changes in tumors from $\mathrm{H}_{22}$ tumor-bearing mice. (A) Tumor tissue sections stained by $\mathrm{H} \& \mathrm{E}(\times 100)$, (B) tumor tissue sections stained by H\&E ( $\times 400)$, (C) tumor tissue sections stained by TUNEL. (a) Untreated广, (b) CTX广, (c) chiisanoside $\dagger 60$ mg kg ${ }^{-1}$, (d) chiisanoside $\uparrow 120 \mathrm{mg} \mathrm{kg}^{-1}$, (e) chiisanoside $\uparrow 240 \mathrm{mg} \mathrm{kg}^{-1}\left(\dagger=\mathrm{H}_{22}\right.$ tumor-bearing ICR mice). 
A
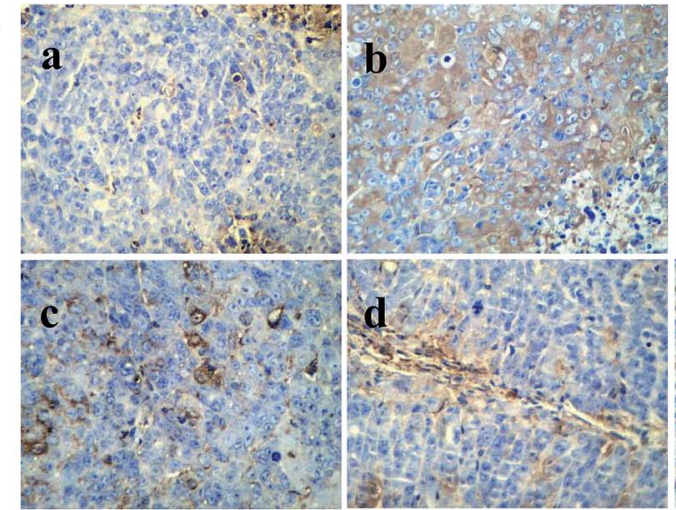

B
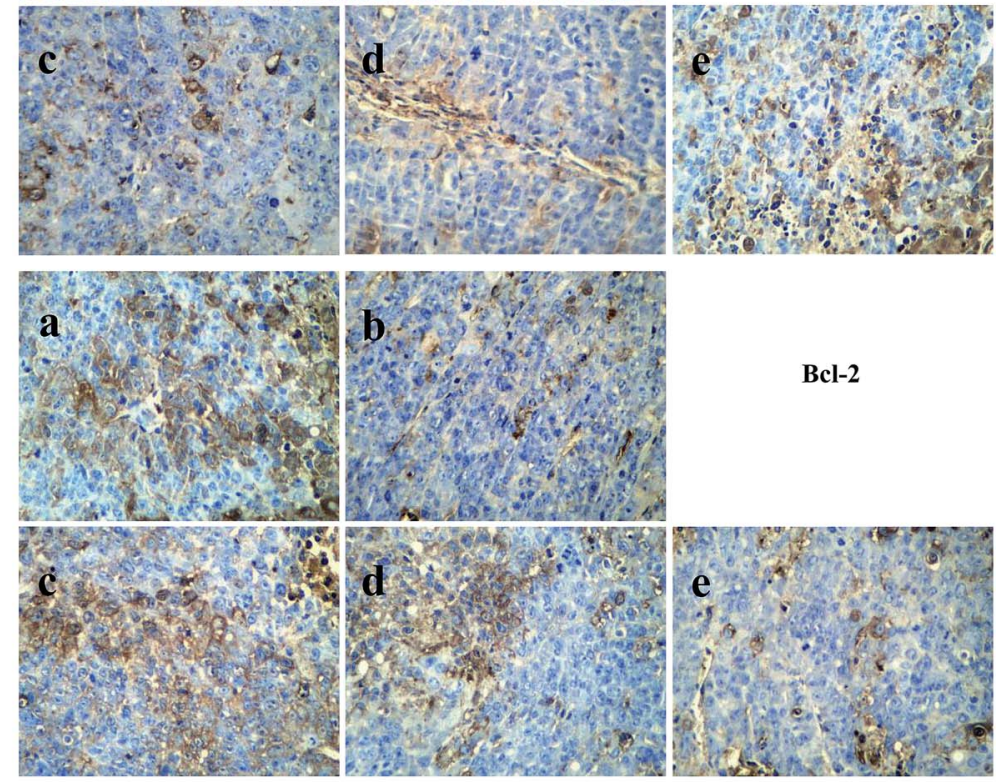

C
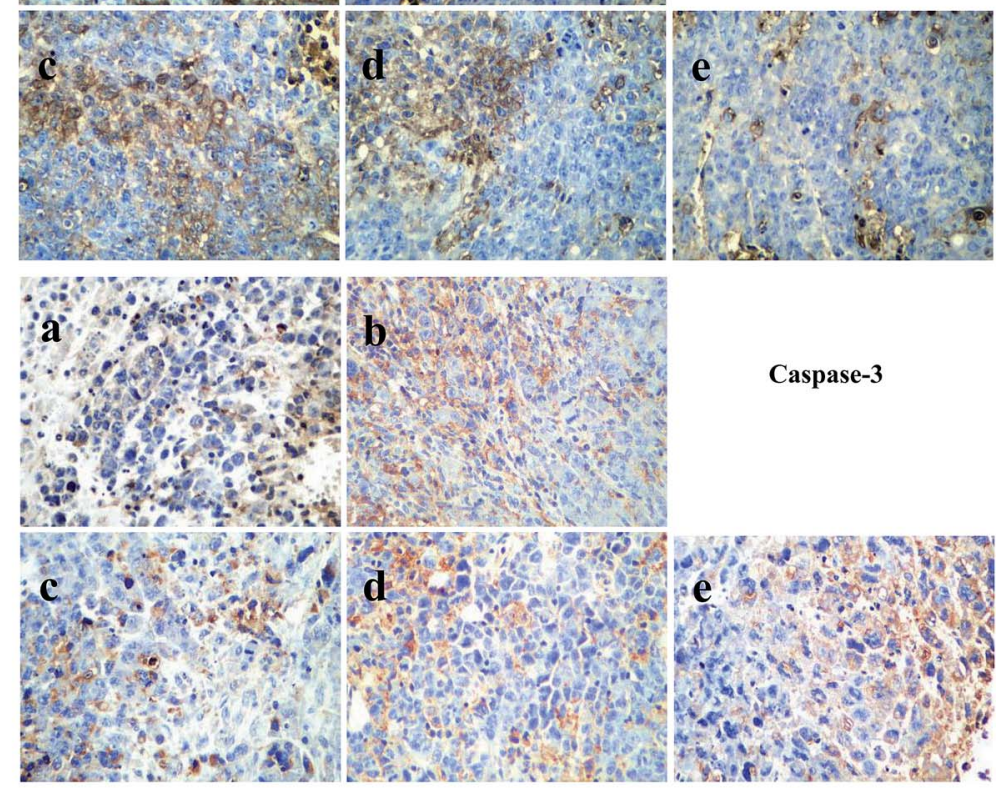

D
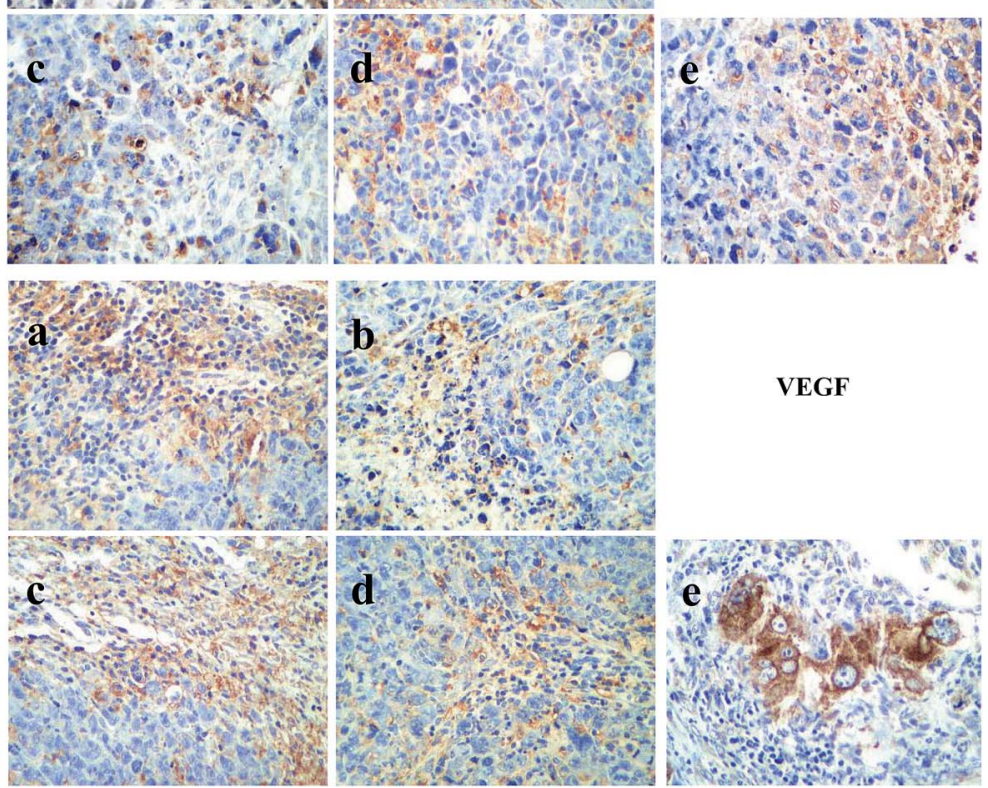

Fig. 5 Effects of chiisanoside on protein expression of Bax, Bcl-2, caspase-3 and VEGF by immunohistochemistry in (a). (A) Bax ( $\times 400)$, (B) Bcl-2

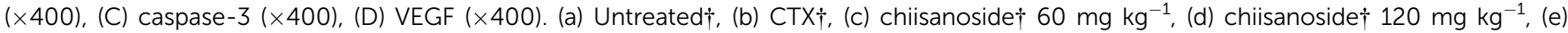
chiisanoside $\dagger 240 \mathrm{mg} \mathrm{kg}^{-1}\left(\dagger=\mathrm{H}_{22}\right.$ tumor-bearing ICR mice). 
that of model control group in a dose-dependent manner. Whereas, things came to be different in anti-apoptotic proteins. The results were shown in Fig. 5B. Comparing with model control, Bcl-2 protein was down-regulated significantly when treated with chiisanoside of $60,120,240 \mathrm{mg} \mathrm{kg}^{-1}$, respectively. In addition, to evaluate whether chiisanoside administration exhibits function on inhibition of tumor growth, the tumor sections was stained and performed immunohistochemical analysis on VEGF after 10 day treatment. The high expression level of VEGF were observed in tumor tissue sections of model control group as showed in Fig. 5D, and chiisanoside could dramatically inhibit the expression of VEGF in tumor tissue, which was consistent with that in plasma.

\subsection{Calibration curves}

The calibration curves showed good linearity over the concentration. The linear regression of the curve for the peak area ratio of chiisanoside to Rd $(y)$ versus the concentration of chiisanoside $(x)$ was plotted ( $r \geq 0.999)$. Calibration curves in rat plasma and different tissues, including liver, heart, spleen, lung, kidney, stomach, brain and small intestine were listed in Table 2. The lowest limit of quantification of the study was $0.1 \mu \mathrm{g} \mathrm{mL}{ }^{-1}$.

\subsection{Pharmacokinetics study and tissue distribution}

The method presented in this study was validated, and was successfully applied in pharmacokinetics study of chiisanoside at three doses. The mean plasma concentration $v s$. time after intravenous infusion administration of different doses of chiisanoside was shown in Fig. 6, while major pharmacokinetics parameters of chiisanoside were calculated by a noncompartment model and listed in Table 3 . The results indicated that the plasma concentrations of chiisanoside increased rapidly after intravenous infusion administration, and reached the peak concentration at $0.083-0.3 \mathrm{~h}$. Furthermore, the parameter of $t_{1 / 2 z}$ showed chiisanoside could also be cleared rapidly from rat plasma. Also, there was a good correlation between the dose and AUC.

The tissue distribution of chiisanoside was investigated in Wistar rats at 2,10 and 40 min after tail intravenous infusion of

Table 2 Calibration curves of chiisanoside in rat plasma and tissue homogenate

\begin{tabular}{lll}
\hline Samples & Calibration curves & $\begin{array}{l}\text { Linear ranges } \\
\left.(\mu \mathrm{g} \mathrm{mL})^{-1}\right)\end{array}$ \\
\hline Plasma & $y=0.0609 x-0.0017$ & $0.1-5$ \\
Plasma & $y=0.0267 x+0.2026$ & $5-500$ \\
Liver & $y=0.0406 x+0.0046$ & $0.1-100$ \\
Heart & $y=0.0343 x+0.0332$ & $0.1-100$ \\
Spleen & $y=0.0461 x-0.2274$ & $0.1-100$ \\
Lung & $y=0.0294 x+0.0702$ & $0.1-100$ \\
Kidney & $y=0.0269 x+0.0594$ & $0.1-100$ \\
Brain & $y=0.0415 x-0.0642$ & $0.1-100$ \\
Stomach & $y=0.0275 x+0.016$ & $0.1-100$ \\
Small intestine & $y=0.0346 x+0.002$ & $0.1-100$
\end{tabular}

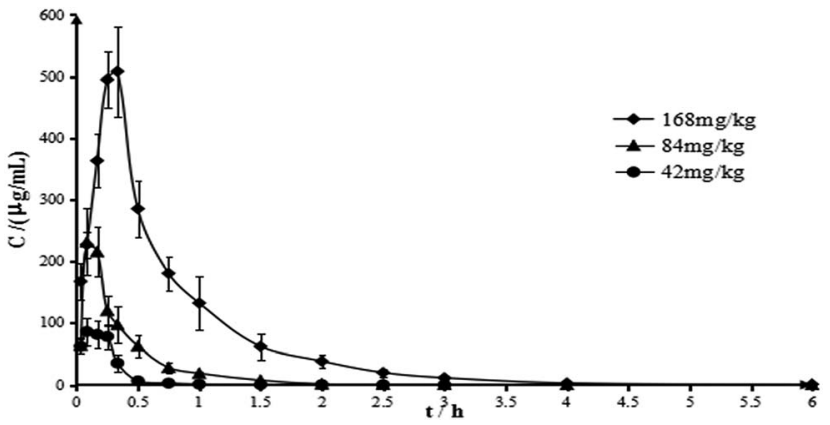

Fig. 6 Mean plasma concentration-time curves of chiisanoside in rats by intravenous infusion administration. All values were expressed as mean $\pm S D, n=6$.

Table 3 Pharmacokinetics parameters of chiisanoside in rats by intravenous infusion administration

\begin{tabular}{llccc}
\hline & \multicolumn{4}{c}{ Chiisanoside } \\
\cline { 3 - 5 } Parameter & Unit & Low dose & Medium dose & High dose \\
\hline$C_{\text {max }}$ & $\mu \mathrm{g} \mathrm{mL}{ }^{-1}$ & 86.579 & 230.121 & 512.087 \\
$T_{\text {max }}$ & $\mathrm{h}$ & 0.125 & 0.083 & 0.319 \\
$t_{1 / 2 z}$ & $\mathrm{~h}$ & 1.369 & 3.787 & 1.092 \\
$\mathrm{MRT}_{(0-t)}$ & $\mathrm{h}$ & 0.326 & 0.478 & 0.816 \\
$\operatorname{MRT}_{(0-\infty)}$ & $\mathrm{h}$ & 0.506 & 0.672 & 0.827 \\
$\operatorname{AUC}_{(0-t)}$ & $\mu \mathrm{g} \mathrm{h} \mathrm{mL}$ & \\
$\operatorname{AUC}_{(0-\infty)}$ & $\mu \mathrm{g} \mathrm{h} \mathrm{mL}$ & 29.715 & 94.134 & 374.262 \\
& & 30.489 & 95.016 & 374.71
\end{tabular}

$84 \mathrm{mg} \mathrm{kg}{ }^{-1}$ (Fig. 7). After 2 minutes, all kinds of tissues were contained chiisanoside except lung. After $10 \mathrm{~min}$ of administration, chiisanoside was detected in all tissues, and the highest concentration was $42.04 \mu \mathrm{g} \mathrm{mL}^{-1}$ in liver, then followed by small intestine $\left(28.73 \mu \mathrm{g} \mathrm{mL} \mathrm{m}^{-1}\right)$, next was the kidney $\left(12.63 \mu \mathrm{g} \mathrm{mL} \mathrm{m}^{-1}\right)$, and the lowest concentration was in brain $\left(2.02 \mu \mathrm{g} \mathrm{mL}^{-1}\right)$. After $40 \mathrm{~min}$, the concentration of chiisanoside in the organs were gradually decreased except in the liver. As for the three time points, the results demonstrated that chiisanoside mainly distributed in liver and small intestine after tail intravenous infusion.

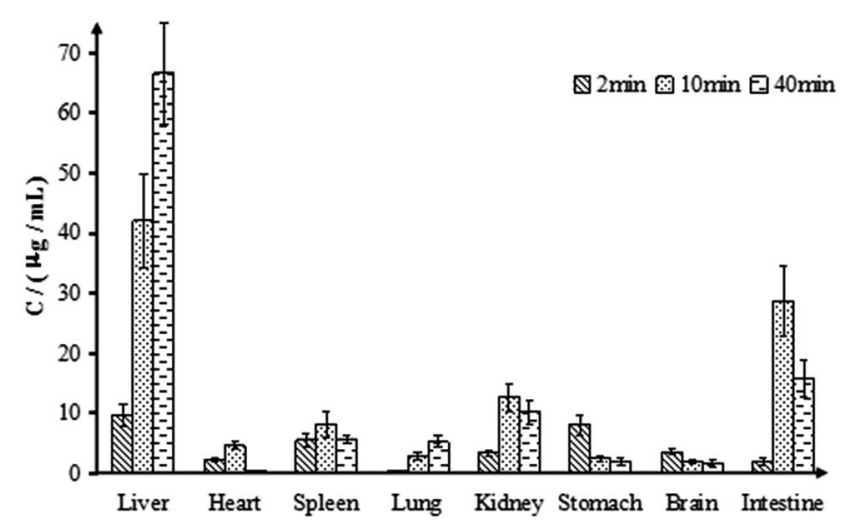

Fig. 7 The distribution of chiisanoside in main tissue samples in rats by intravenous infusion administration. All values were expressed as mean $\pm \mathrm{SD}, n=6$ 


\section{Discussion}

In this study, a $\mathrm{H}_{22}$ tumor-bearing mouse model was established to investigate the anti-tumor activities of chiisanoside by intraperitoneal injection. The results showed that chiisanoside could effectively inhibit the growth of $\mathrm{H}_{22}$ hepatoma transplanted tumor, with a dose-dependent manner. The inhibition rate of chiisanoside $240 \mathrm{mg} \mathrm{kg}^{-1}$ treated reached $66.45 \%$ that was higher than that of CTX which is a conventional chemotherapeutic anti-tumor drug. As is known to all, though CTX exerts strong anti-tumor activity, it has serious toxic effect to body as it is one of immunosuppressive agents, which was also confirmed in this experiment. At the end of the 10 day treatment, all organ indices of mice in CTX group were decreased dramatically. The decline of liver index in CTX group corresponded to the report that CTX had serious hepatotoxicity. Also, the plasma ALT level in CTX treated mice was higher than those in normal and chiisanoside groups, which indicated side effects on liver. On the contrary, chiisanoside treatment increased the liver index and decreased the plasma ALT level. Additionally, chiisanoside treatment increased the indices of thymus and spleen, which indicated that chiisanoside exhibited no negative influence on immunologic system. All above of these demonstrated that chiisanoside exhibited positive effect on inhibition of tumor growth with no side effects to immune organs.

The occurance of tumor growth is closely related to the plasma cytokines, such as IL-2, TNF- $\alpha$, IFN- $\gamma$ and VEGF. ${ }^{35,36}$ IL-2 can promote the proliferation and differentiation of $\mathrm{T}$ lymphocytes, induce cytotoxic cells with cytotoxic activity, and induce and enhance the activity of killer T cells, monocytes and macrophages. ${ }^{37,38}$ TNF- $\alpha$ derives from mononuclear phagocyte, making significant effects on promoting tumor cell apoptosis and cell necrosis. ${ }^{39}$ As for IFN- $\gamma$, it exhibits antiviral, immunomodulatory and antitumor properties. ${ }^{40}$ VEGF is one of the important factors to promote tumor growth and metastasis. ${ }^{\mathbf{4 1}}$ This study indicated that chiisanoside could inhibite the tumor growth by increasing the plasma levels of IL-2, TNF- $\alpha$ and IFN- $\gamma$, while down-regulated the plasma level of VEGF.

By H\&E and TUNEL staining, scattered distribution of the apoptotic cells could be seen in chiisanoside treatment groups. To further investigate the mechanism of apoptosis, immunohistochemical assay was performed to determine the impact of chiisanoside on Bax, Bcl-2, VEGF and caspase-3. Cell development and homeostasis are regulated by anti-apoptotic proteins, such as Bcl-2 and VEGF, and pro-apoptotic proteins including caspase- 3 and Bax. High expression levels of Bax and caspase- 3 can promote the tumor cell apoptosis, while high expression levels of Bcl-2 and VEGF may suppress the occurance of tumor cell apoptosis. The immunohistochemical assay of this study indicated that the anti-tumor effect of chiisanoside was related with up-regulated proteins of Bax and casepase-3, and downregulated proteins of Bcl-2 and VEGF.

On the basis of anti-tumor research, the pharmacokinetics and tissue distribution of chiisanoside were investigated in rat. Doses given for pharmacokinetics were transformed according to the pharmacology experiment and the experimental animal's body surface area principle. As the data of pharmacokinetics parameter shown, chiisanoside had a trait of fast absorption and rapid elimination. Combing with the analysis of anti-tumor assay, the medium dose $\left(120 \mathrm{mg} \mathrm{kg}^{-1}\right)$ was regarded as the effective dose to determine the tissue distribution, and the results indicated that chiisanoside could be fastly and widely distributed in various tissues, such as liver, heart, spleen, lung, kidney, stomach, brain and small intestine. The drug concentration in liver and small intestine were higher than those in other tissues, which indicated chiisanoside showed good liver and small intestine targeting efficiency. It was speculated that the small intestinal absorption and liver metabolish were one of the principle factors influencing the drug distribution. In contrast, the lower concentration in heart, spleen and lung illustrated that blood flow and perfusion rate of organ did not the important factors for distribution.

In conclusion, chiisanoside showed significantly anti-tumor effect, the mechanism may be derived from the immunoregulation and anti-angiogenesis activity, as well as the promoting apoptosis of tumor cell. It is worth mentioning that chiisanoside was mainly distributed in liver, which may have positive influence on treatment for hepatic carcinoma.

\section{Conflicts of interest}

There are no conflicts of interest to declare.

\section{Acknowledgements}

The authors are grateful for the Special Fund for Agro-scientific Research in the Public Interest (grant No. 201303111) and Jilin Province Science and Technology Development Program (grant No. 20160307005YY, 20150307012YY). We declare that there are no financial or other contractual agreements that might cause conflicts of interest or be perceived as causing conflicts of interest.

\section{References}

1 R. Wang, et al., Incidence and mortality of liver cancer in mainland China: changes in first decade of 21st century, Hepatogastroenterology, 2015, 62(137), 118-121.

2 A. Forner, J. M. Llovet and J. Bruix, Hepatocellular carcinoma, Lancet, 2012, 379(9822), 1245-1255.

$3 \mathrm{X}$. Zhao, et al., A flavonoid component from Docynia delavayi (Franch.) Schneid represses transplanted $\mathrm{H}_{22}$ hepatoma growth and exhibits low toxic effect on tumor-bearing mice, Food Chem. Toxicol., 2012, 50(9), 3166-3173.

4 A. Szakiel, et al., Comparison of the triterpenoid content of berries and leaves of lingonberry Vaccinium vitis-idaea from Finland and Poland, J. Agric. Food Chem., 2012, 60(19), 4994-5002.

5 M. K. Shanmugam, et al., Oleanolic acid and its synthetic derivatives for the prevention and therapy of cancer: preclinical and clinical evidence, Cancer Lett., 2014, 346(2), 206-216. 
6 L. S. Gan, et al., Cycloartane triterpenoids from Kleinhovia hospita, J. Nat. Prod., 2009, 72(6), 1102-1105.

7 E. H. Kim, et al., CDDO-imidazolide induces DNA damage, G2/M arrest and apoptosis in BRCA1-mutated breast cancer cells, Cancer Prev. Res., 2011, 4(3), 425-434.

8 Y. Zhang, et al., Studies on cytotoxic triterpene saponins from the leaves of Aralia elata, Food Chem., 2013, 138(1), 208-213.

9 L. Yu, et al., Triterpenoid saponins from Xanthoceras sorbifolia Bunge and their inhibitory activity on human cancer cell lines, Bioorg. Med. Chem. Lett., 2012, 22(16), 5232-5238.

10 M. K. Shanmugam, et al., Ursolic acid in cancer prevention and treatment: molecular targets, pharmacokinetics and clinical studies, Biochem. Pharmacol., 2013, 85(11), 15791587.

$11 \mathrm{H}$. Morita, et al., Antimitotic quinoid triterpenes from Maytenus chuchuhuasca, Bioorg. Med. Chem. Lett., 2008, 18(3), 1050-1052.

12 V. Lanzotti, et al., Paviosides A-H, eight new oleane type saponins from Aesculus pavia with cytotoxic activity, Bioorg. Med. Chem., 2012, 20(10), 3280-3286.

13 Y. C. Soo, et al., Measurement of characteristic phytochemical levels in different Acanthopanax species by HPLC, Yakhak Hoeji, 2017, 61(2), 90-95.

$14 \mathrm{~J}$. M. Lee, et al., Quantitative analysis of chiisanoside in Acanthopanax species by HPLC, Nat. Prod. Sci., 2007, 13(2), 148-151.

$15 \mathrm{~J}$. S. Kang, et al., Determination of chiisanoside in Acanthopanax species by High Performance Liquid Chromatography, Nat. Prod. Sci., 2003, 9(2), 45-48.

16 Y. Ding, et al., Chiisanoside, a lupane triterpenoid from Acanthopanax leaves, stimulates proliferation and differentiation of osteoblastic MC3T3-E1 cells, Nat. Prod. Sci., 2008, 14(1), 21-26.

17 H. J. Jung, et al., Antiinflammatory effects of chiisanoside and chiisanogenin obtained from the leaves of Acanthopanax chiisanensis in the carrageenan- and Freund's complete adjuvant-induced rats, $J$. Ethnopharmacol., 2005, 97(2), 359-367.

18 S. K. Park, et al., Inhibitory effects of chiisanoside and acanthoside on the allergic inflammation, Mol. Cell. Toxicol., 2007, 3(4), 60.

$19 \mathrm{~J} . \mathrm{H}$. Won, et al., Inhibition of lipopolysaccharide-induced expression of inducible nitric oxide and cyclooxygenase-2 by chiisanoside via suppression of nuclear factor- $\kappa \mathrm{B}$ activation in RAW 264.7 macrophage cells, Biol. Pharm. Bull., 2005, 28(10), 1919-1924.

20 D. Y. Lee, et al., Bioactive 3,4-seco-triterpenoids from the fruits of Acanthopanax sessiliflorus, Biol. Pharm. Bull., 2012, 75(6), 1938-1944.

21 S. H. Lee, et al., Antibacterial compounds from the leaves of Acanthopanax senticosus, Arch. Pharmacal Res., 2003, 26(1), 40-42.

22 J. L. Jin, et al., Platelet anti-aggregating triterpenoids from the leaves of Acanthopanax senticosus and the fruits of A. sessiliflorus, Planta Med., 2004, 70(6), 564-566.
23 H. Y. Kim, et al., Protective effects of 3,4-seco-lupane type triterpenes from Acanthopanax senticosus against advanced glycation endproducts, Hortic., Environ. Biotechnol., 2012, 53(3), 242-246.

24 E. A. Bae, et al., Metabolism of chiisanoside from Acanthopanax divaricatus var. albeofructus by human intestinal bacteria and its relation to some biological activities, Biol. Pharm. Bull., 2001, 24(5), 582-585.

$25 \mathrm{~K}$. Yoshizumi, et al., Chiisanoside is not absorbed but inhibits oil absorption in the small intestine of rodents, Biosci., Biotechnol., Biochem., 2008, 72(4), 1126-1129.

$26 \mathrm{~K}$. Yoshizumi, et al., Lupane-type saponins from leaves of Acanthopanax sessiliflorus and their inhibitory activity on pancreatic lipase, J. Agric. Food Chem., 2006, 54(2), 335-341.

27 G. L. Chen, et al., Flavored black ginseng exhibited antitumor activity via improving immune function and inducing apoptosis, Food Funct., 2017, 8(7), 1880-1889.

28 T. Wang, et al., Enhanced tumor delivery and antitumor activity in vivo of liposomal doxorubicin modified with MCF-7-specific phage fusion protein, Nanomedicine, 2014, 10(2), 421-430.

29 H. M. Qu, S. J. Liu and C. Y. Zhang, Antitumor and antiangiogenic activity of Schisandra chinensis polysaccharide in a renal cell carcinoma model, Int. J. Biol. Macromol., 2014, 66, 52-56.

$30 \mathrm{Z}$. Sun, et al., Development and validation of a sensitive UHPLC-MS/MS method for quantitation of prucalopride in rat plasma and its application to pharmacokinetics study, J. Chromatogr. B: Anal. Technol. Biomed. Life Sci., 2016, 1033, 328-333.

$31 \mathrm{P}$. Zhang, et al., Pharmacokinetics in rats and efficacy in murine ovarian cancer model for solid lipid nanoparticles loading docetaxel, J. Nanosci. Nanotechnol., 2010, 10(11), 7541-7544.

32 N. Zhang, et al., Pharmacokinetics, tissue distribution and anti-tumor effect of low density lipoprotein peptide conjugated submicron emulsions, Biomed. Pharmacother., 2016, 82, 614-619.

33 A. M. Mesa, et al., Stallion Semen Incubated with Hydrogen Peroxide Decreased DNA Fragmentation as Measured by the TUNEL Assay, J. Equine Vet. Sci., 2017, 49, 81-86.

$34 \mathrm{~J}$. Su, et al., Anti-tumor and anti-virus activity of polysaccharides extracted from Sipunculus nudus(SNP) on Hepg2.2.15, Int. J. Biol. Macromol., 2016, 87, 597-602.

35 C. Chen, et al., Pharmacokinetics and pharmacodynamics of gastroretentive delivery of levodopa/carbidopa in patients with Parkinson disease, Clin. Neuropharmacol., 2012, 35(2), 67-72.

36 G. Wang, et al., Enhancement of IL-2 and IFN-gamma expression and NK cells activity involved in the anti-tumor effect of ganoderic acid Me in vivo, Int. Immunopharmacol., 2007, 7(6), 864-870.

37 S. A. Rosenberg, IL-2: the first effective immunotherapy for human cancer, J. Immunol., 2014, 192(12), 5451-5458.

38 I. D. Kumalasari, et al., Immunomodulatory activity of Bengkoang (Pachyrhizus erosus) fiber extract in vitro and in vivo, Cytotechnology, 2014, 66(1), 75-85. 
39 F. J. Lejeune, et al., Efficiency of recombinant human TNF in human cancer therapy, Cancer Immun., 2006, 6, 6.

$40 \mathrm{~K}$. Kuwahara, et al., Nadifloxacin, an antiacne quinolone antimicrobial, inhibits the production of proinflammatory cytokines by human peripheral blood mononuclear cells and normal human keratinocytes, J. Dermatol. Sci., 2005, 38(1), 47-55.

41 N. K. Sah, et al., Structural, functional and therapeutic biology of survivin, Cancer Lett., 2006, 244(2), 164-171. 